\title{
Expressão gênica de caspases 3 e 8 em timo e baço de ratas recém-desmamadas e imunossuprimidas por glicocorticóide
}

[Genic expression of caspases 3 and 8 in thymus and spleen of glicocorticoid-immunossupressed weaned rats]

\author{
J.J. Batista ${ }^{1}$, A.S. Martins ${ }^{2}$, L. Moro ${ }^{1}$, A.C. Vasconcelos ${ }^{1}$ \\ ${ }^{1}$ Departamento de Patologia Geral - Instituto de Ciências Biológicas - UFMG \\ Caixa Postal 486 \\ 31270-901 - Belo Horizonte, MG \\ ${ }^{2}$ Departamento de Fisiologia - ICB - UFMG - Belo Horizonte, MG
}

\begin{abstract}
RESUMO
Determinou-se a expressão gênica das caspases 3 e 8 mediante transcrição reversa de mRNA total e reação em cadeia da polimerase (RT-PCR) para avaliar a apoptose em timo e baço de ratas imunossuprimidas por glicocorticóides. Utilizou-se dexametasona para indução da apoptose e atrofia linfóide. Quarenta e cinco fêmeas Wistar recém-desmamadas foram separadas em três grupos: as ratas de A $(n=18)$ e B $(n=18)$ foram tratadas com 250 e $500 \mathrm{mg}$ de glicocorticóide, via intramuscular, respectivamente, e as do $\mathrm{C}(\mathrm{n}=9)$ não foram tratadas. Após 24, 48 e 72 horas, seis animais de cada grupo tratado e três do controle foram anestesiados, pesados e sacrificados. O baço e o timo foram coletados e pesados. Fragmentos dos órgãos foram fixados em formol tamponado a $10 \%$ e processados segundo técnica para inclusão em parafina. Os blocos foram seccionados em $5 \mu \mathrm{m}$, e os cortes corados em hematoxilina e eosina. A análise histopatológica aliada ao peso dos órgãos nas diferentes doses e tempos demonstrou que a dexametasona induziu hipotrofia linfóide, que ocorreu com maior intensidade no tempo de 72 horas em animais do grupo B. Fragmentos de timo e de baço foram imediatamente congelados em nitrogênio líquido para extração de mRNA e DNA. Para a padronização da técnica de RT-PCR, utilizaram-se pool de amostras de mRNA dos animais-controle e pool de mRNA de animais tratados em cada tempo de experimento. A técnica de RT-PCR foi sensível o suficiente para a detecção dos mRNAs que codificam as caspases 3 e 8 , e ambas participaram do processo de apoptose induzido por dexametasona.
\end{abstract}

Palavras-chave: rato, apoptose, dexametasona, timo, baço, caspase 3, caspase 8, RT-PCR

\begin{abstract}
Expression of caspases 3 and 8 in spleen and thymus of immunosuppressed rats was analyzed by the reverse transcriptase-polymerase chain reaction (RT-PCR). Forty-five weaned female Wistar rats were divided into three groups: $A(n=18)$ and $B(n=18)$ rats were injected with $250 \mu \mathrm{g}$ and $500 \mu \mathrm{g}$ per rat, respectively; and $C(n=9)$ rats were non-treated control animals. After 24, 48 and 72 hours, six animals from $A$ and $B$ groups and three controls were anaesthetized with chloroform, weighed and euthanized. Thymus and spleens were collected, weighed and a sample of each organ was fixed by immersion in 10\% buffered formaline and embedded in paraffin. Thin sections $(5 \mu \mathrm{m})$ were stained with HE. Thymus and spleen samples were snap frozen in liquid nitrogen and stored at $-80^{\circ} \mathrm{C}$ for total RNA and DNA extraction. Apoptotic indices were calculated using sections stained with HE. Apoptotic indices and organs weights showed that hypotrophy happened mainly at $72 \mathrm{~h}$ post treatment with $500 \mu \mathrm{g} / \mathrm{rat}$. RT-PCR was standardized using a pool of control animals and another from treated animals with $A$ and $B$ doses at each time period, respectively. Specific oligonucleotides for caspases 3 and 8 were drawn to obtain
\end{abstract}

Recebido para publicação em 22 de janeiro de 2004

Recebido para publicação, após modificações, em 13 de agosto de 2004

E-mail: moro@icb.ufmg.br 


\section{Batista et al.}

fragments of $271 \mathrm{bp}$ and $368 \mathrm{bp}$, respectively. The results demonstrated that technique RT-PCR is sensitive enough to detect caspases 3 and 8 mRNAs and that caspase 3 and 8 participate in the apoptotic process induced by dexamethasone in weaned rats.

Keywords: rat, apoptosis, dexamethasone, thymus, spleen, caspase 3, caspase 8, RT-PCR

\section{INTRODUÇÃO}

A apoptose é um tipo ativo de morte celular que requer energia, síntese e degradação protéicas para sua execução (Kerr e Searle, 1972), sendo, portanto, um processo ordenado que ocorre por meio da ativação e expressão de genes, gerando diversas enzimas necessárias para a autodestruição celular (Kerr, 1971; Kerr et al., 1972). É um processo diferente da necrose, que ocorre quando uma agressão externa intensa medeia a destruição da membrana citoplasmática ou do suporte bioquímico dessa integridade (Collins et al., 1997). A apoptose ocorre freqüentemente como resultado da diferenciação terminal em células lábeis e estáveis, sendo importante na homeostasia de organismos multicelulares (Wyllie et al., 1980). A morte celular fisiológica ocorre na maturação imunológica, incluindo a supressão de clones não reativos e auto-reativos no timo, também chamadas de seleção negativa e positiva, respectivamente. A morte de células-alvo (infectadas ou transformadas) por linfócitos citotóxicos e células killer também ocorre por apoptose (Arends e Wyllie, 1991).

As mudanças morfológicas observadas no processo de apoptose são condensação celular, presumivelmente pela perda de água (Kerr et al., 1972); desprendimento e arredondamento celular; projeções da membrana citoplasmática; condensação da cromatina nuclear (Mills, 1999; Hacker, 2000) e fragmentação nuclear e celular em corpos apoptóticos. A maioria dessas mudanças é mediada por uma cascata enzimática envolvendo cisteíno-proteases, chamadas caspases, que clivam resíduos de ácido aspártico (Hengartner, 2000). Atualmente, já foram identificadas 14 caspases (Abbas et al., 2000) que podem ser classificadas em iniciadoras $(2,8$, 9 e 10) e executoras (3, 6 e 7) (AmaranteMendes e Green, 1999).

Além das alterações morfológicas, ocorrem eventos bioquímicos marcantes como a fragmentação internucleossômica do genoma.

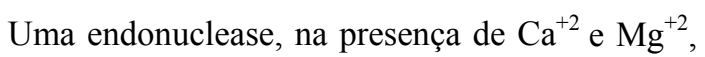
cliva o DNA em subunidades com cerca de 180 a $200 \mathrm{pb}$ ou múltiplos desses. Essa fragmentação internucleossômica pode ser visualizada através da eletroforese do DNA em gel de agarose, gerando o clássico padrão em escada (Wyllie, 1980). Os objetivos do trabalho foram desenvolver iniciadores específicos de oligonucleotídeos para transcrição reversa e amplificação de regiões-alvo dos mRNAs das caspases 3 e 8 de rato e avaliar qualitativamente sua expressão em timo e baço de ratas normais e imunossuprimidas por glicocorticoidoterapia.

\section{MATERIAL E MÉTODOS}

Quarenta e cinco fêmeas Wistar recémdesmamadas (21 a 24 dias) foram divididas em três grupos experimentais: (A) tratamento com $250 \mu \mathrm{g}$ de fosfato dissódico de dexametasona/animal via intramuscular $(n=18)$, (B) tratamento com $500 \mu \mathrm{g}$ de fosfato dissódico de dexametasona/animal via intramuscular $(\mathrm{n}=$ 18) e (C) controle não-tratados $(n=9)$. Seis animais dos grupos $\mathrm{A}$ e $\mathrm{B}$ e três do $\mathrm{C}$ foram sorteados nos períodos de 24,48 e 72 horas após a aplicação do corticóide, anestesiados com clorofórmio, pesados, sacrificados e necropsiados. Os timos e os baços foram pesados. Fragmentos dos órgãos foram fixados em formol tamponado a $10 \%$ e processados segundo técnica de inclusão em parafina. Os blocos foram seccionados a $5 \mu \mathrm{m}$ e corados em hematoxilina-eosina (HE). As secções coradas foram examinadas ao microscópico óptico para a verificação morfológica da ocorrência de apoptose. Foram consideradas células em apoptose somente aquelas que apresentaram pelo menos três critérios de inclusão: anoiquia (retração celular e perda de adesões entre células e membrana basal), condensação do citoplasma, condensação nuclear (compactação da cromatina nuclear em massas densas uniformes, alinhadas no lado interno da membrana nuclear, inclusive com aspecto de crescentes), fragmentação nuclear (convolução e fragmentação da 
membrana nuclear - sem cariorrexe ou ruptura), fragmentação celular (com formação dos corpos apoptóticos), fagocitose dos corpos apoptóticos pelas células adjacentes (canibalismo celular) e ausência de inflamação.

Fragmentos de timo e de baço foram congelados em nitrogênio líquido, imediatamente após a colheita, e mantidos a $-80^{\circ} \mathrm{C}$. Duzentos miligramas de cada fragmento de tecido foram descongelados, macerados e lisados com tampão de lise hipotônico TTE (10Mm Tris, 0,25\% Triton X-100, 1Mm EDTA). As proteínas foram removidas por extração pelo fenol-clorofórmioálcool isoamílico $(25: 24: 1)$. O DNA foi precipitado com acetato de sódio $3 \mathrm{M}$, lavado em etanol 75\%, seco e ressuspendido em água ultrapura para PCR. Amostras do DNA obtido foram submetidas à eletroforese em gel de agarose a $1,5 \% / 1: 15 \mathrm{~h}$ a $80 \mathrm{~V}$. Os géis de agarose foram corados com brometo de etídio $(0,5 \mu \mathrm{g} / \mu \mathrm{l})$, transiluminados com luz ultravioleta e fotografados.

Para a extração de RNA total, foi utilizada a técnica descrita por Chomczynski e Sacchi (1987). Amostras de 200mg de tecido foram homogeneizadas em $1 \mathrm{ml}$ de solução D (4M isotiocianato de guanidina, $25 \mathrm{Mm}$ de citrato de sódio $\mathrm{pH} \quad 7,0, \quad 0.5 \%$ sarcosil, $0,1 \mathrm{M} \quad 2-$ mercaptoetanol) e transferidas para tubos de $4 \mathrm{ml}$. Adicionaram-se ao homogenato $0,1 \mathrm{ml}$ de

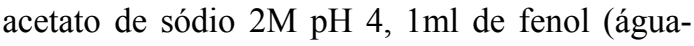
saturado) e $1 \mathrm{ml}$ de clorofórmio:álcool isoamílico (49:1). A suspensão foi agitada por 10 segundos, resfriada em gelo por 15 minutos e centrifugada por 20 minutos a $10000 \mathrm{~g} / 4^{\circ} \mathrm{C}$. A fase aquosa foi transferida para novos tubos. Adicionou-se $1 \mathrm{ml}$ de isopropanol e armazenou-se a $-20^{\circ} \mathrm{C} / 1 \mathrm{~h}$, seguida de centrifugação a $10000 \mathrm{~g} / 20 \mathrm{~min} / 4^{\circ} \mathrm{C}$. $\mathrm{O}$ pélete de RNA foi dissolvido em $0,3 \mathrm{ml}$ de solução $\mathrm{D}$, transferido para um tubo de $1,5 \mathrm{ml}$ e precipitado com um volume de isopropanol $(0,3 \mathrm{ml}) \mathrm{a}-20^{\circ} \mathrm{C}$. O precipitado foi centrifugado a $14000 \mathrm{~g} / 4^{\circ} \mathrm{C} / 10$ minutos, e o pélete de RNA ressuspendido em etanol a $75 \%$ e centrifugado novamente. Os péletes foram secos a vácuo por 15 minutos e diluídos em $100 \mu$ l de água DEPC $(0,5 \mathrm{ml}$ de pirocarbonato dissolvido em água ultrapura - qsp 1 litro - solução autoclavada).

Os oligonucleotídeos iniciadores ou primers de $20 \mathrm{pb}$ foram selecionados com base na análise das seqüências dos cDNAs das caspases 3 e 8 (Juan et al., 1996) descritas no GeneBank, obtidas por meio do programa BLAST (http://www.ncbi. nlm.nih.gov/blast/blast.cgi). Os fragmentos da RT-PCR dentro das regiõesalvo foram de $271 \mathrm{pb}$ e $368 \mathrm{pb}$ para as caspases 3 e 8, respectivamente. Os oligonucleotídeos designados para RT-PCR das caspases 3 e 8 foram, respectivamente: $\left(\mathbf{C 3 F}=5^{\prime}\right.$ AACCTCAGAGAGACATTCAT-3' e $\mathbf{C 3 R}=$ 5'-AGGCCTGAATGATGAAGAGT-3'), e 8 $\left(\mathbf{C 8 F}=5^{\prime}\right.$-GACTGCTTCATCTGCTGCAT-3' e $\mathbf{C 8 R}=$ 5'-AGGCTCTGGCAAAGTGACTG-3').

Para a realização da transcrição reversa (RT) e posterior reação em cadeia da polimerase (PCR), foram feitos pools de RNA dos animais-controle (três animais) para as amostras de timo e de baço e dos animais tratados (seis animais cada) com as doses A e B de dexametasona para as amostras de timo e de baço nos tempos de 24 e 72 horas após administração, separadamente.

Para a padronização da RT, usou-se o protocolo básico utilizado no Laboratório de Fisiologia Geral e Molecular do Departamento de Fisiologia e Biofísica, ICB/UFMG modificado de Frohman (1990). Aplicaram-se 1,6 $\mu 1$ de cada primer (C3R e C8R, a $10 \mathrm{pmol} / \mu \mathrm{l}$ cada) e $9,4 \mu \mathrm{l}(0,5 \mu \mathrm{g} / \mu \mathrm{l}) \mathrm{de}$ RNA total (pool de amostras), incubou-se a $70^{\circ} \mathrm{C} / 10$ minutos. Acrescentaram-se $4 \mu \mathrm{l}$ de tampão de reação 5x (250mM Tris. $\mathrm{HCl}, \mathrm{pH} 8,3$ a $37^{\circ} \mathrm{C}, 40 \mathrm{mM} \mathrm{MgCl}_{2}, 150 \mathrm{mM}$ de $\mathrm{KCl}, 50 \mathrm{mM}$ de DDT), $2 \mu \mathrm{l}$ de dNTP mix e $2 \mu \mathrm{l}$ de $\mathrm{H}_{2} \mathrm{O}$ e incubou-se a $37^{\circ} \mathrm{C} / 2$ minutos. Em seguida, adicionaram-se $2 \mu \mathrm{l}(40 \mathrm{U})$ de enzima transcriptase reversa e incubou-se a $38^{\circ} \mathrm{C} / 60$ minutos. Após a reação de transcrição reversa, os tubos foram mantidos a $4^{\circ} \mathrm{C}$ e foram acrescentados $80 \mu \mathrm{lde}$ $\mathrm{ddH}_{2} \mathrm{O}$ e $200 \mu \mathrm{l}$ de fenol:clorofórmio:álcool isoamílico (25:24:1 volumes) à reação. Centrifugou-se por 15 segundos. Ao sobrenadante foram adicionados $10 \mu 1$ de tampão acetato de sódio $3 \mathrm{M} \mathrm{pH} \mathrm{5,2} \mathrm{e} 220 \mu \mathrm{l}$ de etanol. O cDNA foi precipitado a $-20^{\circ} \mathrm{C} / 1 \mathrm{~h}$ e centrifugado a $14000 \mathrm{~g} / 4^{\circ} \mathrm{C} / 15$ minutos. O pélete foi lavado com etanol $70 \%$, seco ao ar e ressuspendido em $20 \mu \mathrm{l}$ de $\mathrm{H}_{2} \mathrm{O}$ para PCR.

A PCR baseou-se no método descrito por Mullis e Faloona (1987) e em protocolos desenvolvidos e já estabelecidos no laboratório (Carvalho et al., 2000a; Carvalho et al., 2000b). Foi utilizado um protocolo inicial de 45 ciclos térmicos. O 
controle positivo da reação de RT-PCR foi feito utilizando-se de iniciadores específicos para um fragmento de $355 \mathrm{pb}$ para o peptídio natriurético atrial (PNA), e o controle negativo das reações foi realizado pela PCR de tubos contendo água, dNTP mix, tampão, iniciadores, enzima, sem cDNA. Os amplicons foram solubilizados em tampão de amostra 10X (20\% de Ficoll 400; $0,1 \mathrm{M} \mathrm{Na}{ }_{2}$ EDTA, pH 8; 0,1\% de SDS; $0,25 \%$ de azul de bromofenol). Vinte microlitros de cada produto de PCR foram corridos em gel de agarose $1,0 \%$ a $100 \mathrm{~V} / 1 \mathrm{~h}$.

Para confirmar se os fragmentos obtidos pela RT-PCR eram das caspases 3 e 8, os mesmos foram incubados com as endonucleases de restrição Ava/II e Hind/III (10U), respectivamente, por $1 \mathrm{~h}$ a $37^{\circ} \mathrm{C}$. A reação foi bloqueada pela elevação da temperatura a $65^{\circ} \mathrm{C}$ por 10 minutos. As amostras foram analisadas por eletroforese em gel de poliacrilamida corado pela prata.

Os tratamentos foram definidos por esquema fatorial $3 \times 3$ (três tratamentos e três tempos de sacrifício dos ratos recém-desmamados) com três repetições (animais) para cada controle e seis repetições para cada grupo tratado. $\mathrm{O}$ delineamento experimental foi inteiramente ao acaso, usando-se a análise de variância para os dados paramétricos e com distribuição normal para grupos independentes. Valores de $\mathrm{P} \leq 0,05$ foram considerados estatisticamente significativos.

\section{RESULTADOS}

A análise de variância dos pesos relativos dos órgãos obtida para um fator único mostrou diferenças significativas para todas as comparações $\left(\mathrm{P}=1,91 \times 10^{-14}\right)$ para o timo, principalmente, e para o baço $\left(\mathrm{P}=4,82 \times 10^{-4}\right)$ (Tab. 1 e 2).

A coloração de HE foi eficiente para verificação da ocorrência de células em apoptose. Foi evidente a maior ocorrência da apoptose nos órgãos dos animais tratados quando comparados com os do controle. No timo, a apoptose ocorreu mais intensamente na região cortical (Fig. 1) quando comparada com a região medular, particularmente 24 e 72 horas após o tratamento. Após 48 horas, a população de células estava reduzida, mostrando que houve apoptose, porém em intensidade inferior à observada 24 horas após o tratamento.

A eletroforese do DNA genômico das amostras de timo e de baço mostrou o clássico padrão em escada que caracteriza a fragmentação internucleossômica do genoma, tanto nos animais-controle (apoptose fisiológica de linfócitos) quanto nos dos grupos tratados nos períodos de 24, 48 e 72 horas após a inoculação da dexametasona (Fig. 2).

Tabela 1. Valores médios e respectivos erros-padrão dos pesos relativos (\%) do timo de ratas nos diferentes tratamentos e tempos de sacrifício

\begin{tabular}{llllllllll}
\hline & C-24 & A-24 & B-24 & C-48 & A-48 & B-48 & C-72 & A-72 & B-72 \\
\hline Média & 0,526 & 0,188 & 0,220 & 0,389 & 0,112 & 0,106 & 0,354 & 0,079 & 0,084 \\
Erro-padrão & 0,121 & 0,009 & 0,021 & 0,031 & 0,011 & 0,010 & 0,054 & 0,004 & 0,012
\end{tabular}

$\mathrm{P} \leq 0,05$

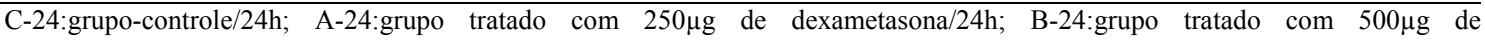
dexametasona/24h; C-48:grupo-controle/48h; A-48:grupo tratado com 250 $\mu \mathrm{g}$ de dexametasona/48h; B-48:grupo tratado com 500 $\mu \mathrm{g}$ de dexametasona/48h; C-72:grupo-controle/72h; A-72:grupo tratado com 250 $\mu$ g de dexametasona/72h; B-72:grupo tratado com $500 \mu \mathrm{g}$ de dexametasona/ $72 \mathrm{~h}$.

Tabela 2. Valores médios e respectivos erros-padrão dos pesos relativos (\%) do baço de ratas nos diferentes tratamentos e tempos de sacrifcio

\begin{tabular}{lccccccccc}
\hline & $\mathrm{C}-24$ & $\mathrm{~A}-24$ & $\mathrm{~B}-24$ & $\mathrm{C}-48$ & $\mathrm{~A}-48$ & $\mathrm{~B}-48$ & $\mathrm{C}-72$ & $\mathrm{~A}-72$ & $\mathrm{~B}-72$ \\
\hline Média & 0,400 & 0,317 & 0,261 & 0,351 & 0,317 & 0,295 & 0,360 & 0,348 & 0,263 \\
Erro-padrão & 0,044 & 0,024 & 0,009 & 0,010 & 0,016 & 0,014 & 0,002 & 0,022 & 0,016 \\
$\mathrm{P} \leq 0,05$ & & & & & & &
\end{tabular}

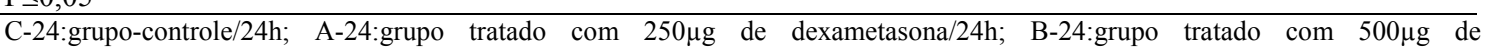
dexametasona/24h; C-48:grupo-controle/48h; A-48:grupo tratado com $250 \mu \mathrm{g}$ de dexametasona/48h; B-48:grupo tratado com 500 $\mu \mathrm{g}$ de dexametasona/48h; C-72:grupo-controle/72h; A-72:grupo tratado com 250 $\mu$ g de dexametasona/72h; B-72:grupo tratado com $500 \mu \mathrm{g}$ de dexametasona/ $72 \mathrm{~h}$. 

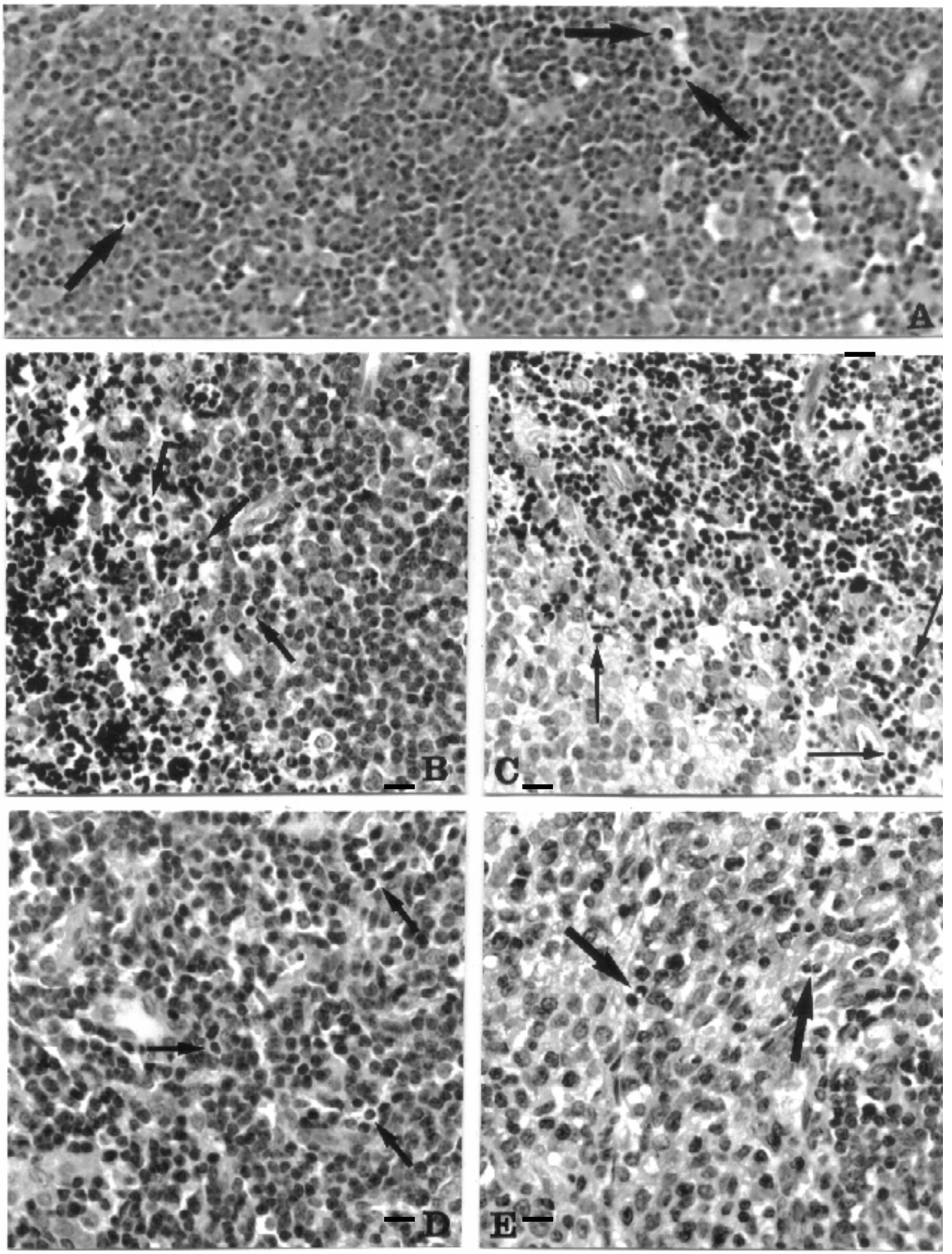

Figura 1. Fotomicrografia de timo mostrando células em apoptose (setas). (A) Timo de animal controle24 horas. Homogeneidade celular em todo o corte e poucas células em apoptose (setas). (B) Timo tratado com $250 \mu \mathrm{g}$ de dexametasona-24 horas. Grande número de células em apoptose na região cortical do tecido (porção esquerda) quando comparada com a região medular (porção direita). (C) Timo tratado com $500 \mu \mathrm{g}$ de dexametasona-24 horas. Grande número de células em apoptose na região cortical (porção superior). (D) Timo tratado com $250 \mu \mathrm{g}$ de dexametasona-48 horas. Observar que o número de células em apoptose é menor quando comparado com os cortes anteriores, B e C, porém maior que o corte A. (E) Timo tratado com $500 \mu \mathrm{g}$ de dexametasona-48 horas. Notar que o mesmo fenômeno do corte D se repete nesse corte. (HE, Barra $=10 \mu \mathrm{m})$. 


\section{Batista et al.}
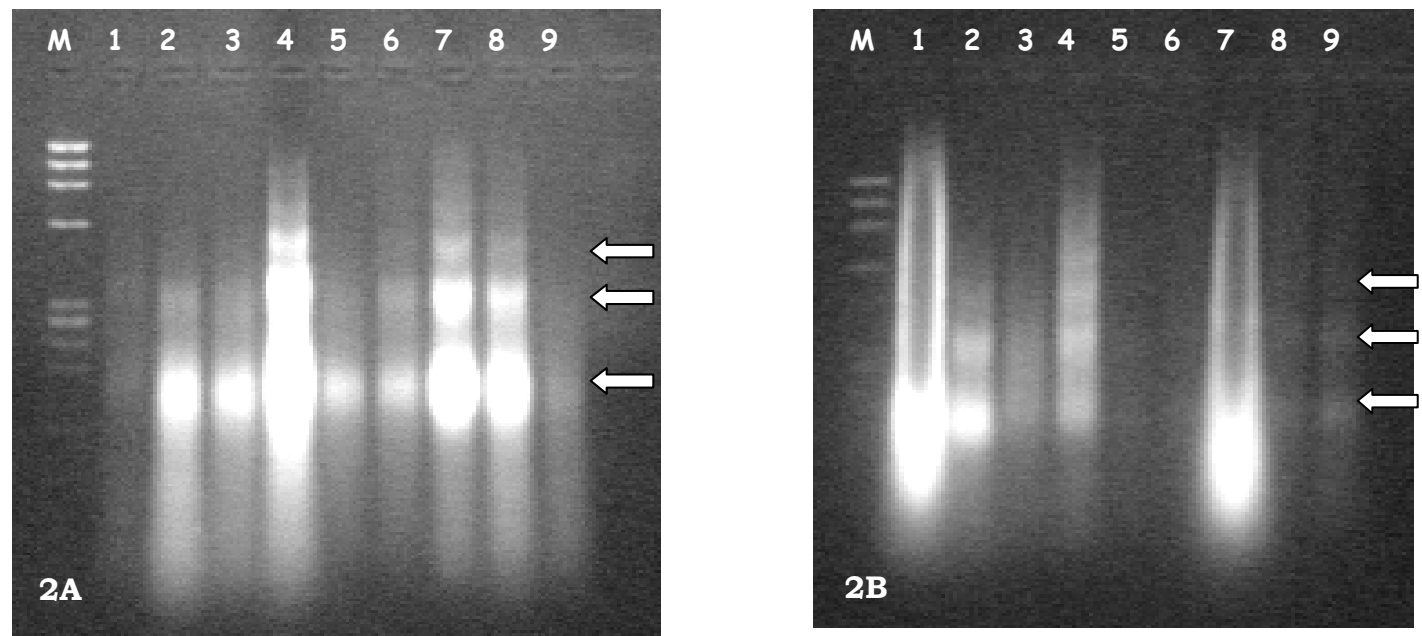

Figura 2. Gel de agarose das amostras de DNA obtidas de baço (2A) e timo (2B) de ratas. Canaletas: 1, 2 e 3 - não tratado e tratados com 250 e $500 \mu \mathrm{g}$ de dexametasona, respectivamente, no tempo de 24 horas; 4 , 5 e 6 - amostras no tempo de 48 horas e 7,8 e 9 - no tempo de 72 horas, na mesma ordem de citação dos tratamentos.

Os resultados qualitativos das reações de RTPCR são mostrados nas Fig. 3 e 4, indicando que houve amplificação das caspases 3 e 8 em todas as amostras.
As eletroforeses mostraram digestão dos produtos incubados com as enzimas, confirmando, assim, que os produtos amplificados eram realmente os genes das caspases 3 e 8 (Fig. 5).
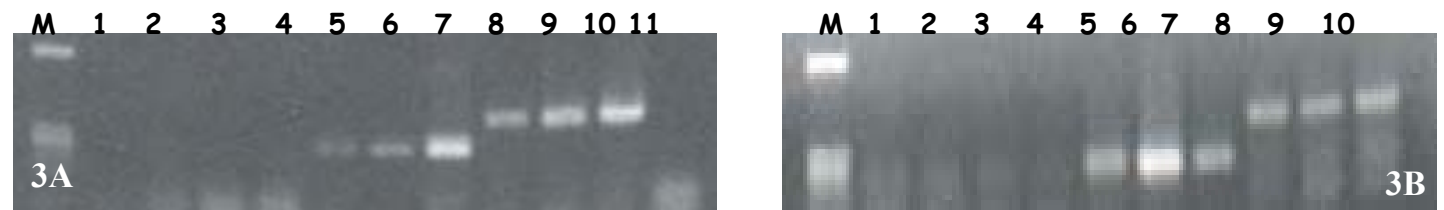

Figura 3. Gel de agarose mostrando o resultado da RT-PCR dos pools de amotras de baço de animaiscontrole e tratados com 250 e $500 \mu \mathrm{g}$ de dexametasona nos tempos de 24 (3A) e 72 horas (3B), respectivamente. M: corresponde ao marcador $\phi X 174$ DNA/BSU RI. Canaletas: 1 - controle positivo; 2 a 4 - PNA em amostras de baço (controle, doses de 250 e $500 \mu \mathrm{g}$, respectivamente; 5 a 7 - caspase 3; 8 a 10 - caspase $8 ; 11$ - controle negativo.
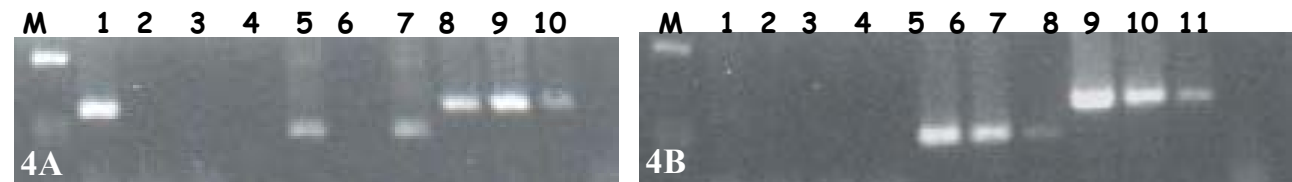

Figura 4. Gel de agarose mostrando o resultado da RT- PCR dos pools de amostras de timo de animaiscontrole e tratados com 250 e $500 \mu \mathrm{g}$ de dexametasona nos tempos de 24 horas (4A) e 72 horas (4B). M: corresponde a marcador $\phi X 174$ DNA/BSU RI. Canaletas: 1 - controle positivo; 2 a 4 - PNA em amostras de baço (controle, doses de 250 e $500 \mu \mathrm{g}$, respectivamente); 5 a 7 - caspase 3; 8 a 10 - caspase $8 ; 11$ - controle negativo. 


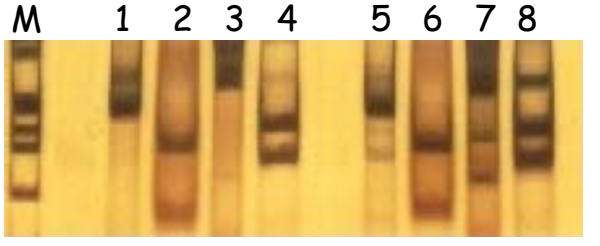

Figura 5. Gel de poliacrilamida mostrando fragmentos liberados após digestão das caspases 3 e 8 com as enzimas de restrição. M: marcador $\phi X 174$ DNA/BSU RI. Canaletas: 1 e 2 - caspase 3 não digerida e digerida $24 \mathrm{~h}$ após tratamento com dexametasona, respectivamente; 3 e 4 caspase 8 não digerida e digerida 24 h após tratamento com dexametasona, respectivamente; 5 e 6 - caspase 3 não digerida e digerida $72 \mathrm{~h}$ após tratamento com dexametasona, respectivamente; 7 e 8 - caspase 8 não digerida e digerida $72 \mathrm{~h}$ após tratamento com dexametasona, respectivamente.

\section{DISCUSSÃO}

A coloração dos cortes de baço e timo em HE evidenciou as alterações morfológicas das células em apoptose. A dexametasona, um dos hormônios corticóides sintéticos, induziu perda de massa do timo e do baço, como pode ser verificado na análise dos pesos relativos desses órgãos (Tab. 1 e 2). A atrofia induzida por dexametasona no timo se associa ao maior número de células em apoptose (King et al., 1995) e admite-se que a apoptose é a forma de morte celular mais comum do sistema imune, com um papel regulador característico (Krammer, 2000). Esse fato foi observado pela análise dos cortes ao microscópio óptico. A detecção da apoptose pela fragmentação internucleossômica do DNA (padrão em escada) visualizada em gel de agarose a 1,5\% (Fig. 2) confirmou a associação entre a hipotrofia do timo e do baço e o aumento de células em apoptose. Essa fragmentação é clássica tanto em células que sofrem apoptose fisiológica quanto em tecidos tratados com substâncias indutoras do processo, como, por exemplo, glicocorticóides. Os tempos de 24 e 72 horas foram escolhidos para a realização da RT-PCR depois de feita a análise microscópica das lâminas juntamente com a análise das médias dos pesos dos órgãos linfóides dos animais-controle e dos tratados com as doses A e B de dexametasona nos três tempos do experimento.

A amplificação das caspases 3 e 8 (Fig. 3 e 4) indica que elas participam do processo de apoptose induzida por dexametasona em ratos Wistar. Kuida et al. (1996) afirmaram que a caspase 3 não participa da via de apoptose induzida por corticosteróide em camundongos. A ativação da caspase $3 \mathrm{em}$ células tratadas com corticosteróides foi relatada por Alam et al. (1997). Miyashita et al. (1998) citaram que a caspase 6 é a principal caspase ativada na indução de apoptose por corticóide. Esses dados sugerem que deve haver mais de uma via para apoptose induzida por corticosteróide, uma com predominância de caspase 3 e outra de caspase 6 (Distelhorst, 2002). Provavelmente, as vias se relacionam com os sistemas celulares e espécies animais utilizados.

A expressão das caspases 3 e 8 foi diferente nos dois tecidos estudados. No baço, 24 horas após o experimento, tanto a caspase 3 quanto a caspase 8 mostraram bandas de intensidade diretamente proporcionais à dose de dexametasona. Essa intensidade crescente das bandas sugere que o número de células em apoptose aumentou com a elevação das doses de dexametasona e que, no tempo de 24 horas, o órgão ainda possuía um número significativo de células que, provavelmente, encontravam-se na fase inicial do processo. O timo mostrou maior intensidade de hipotrofia em relação ao aumento da dose de dexametasona e ao aumento do intervalo de tempo do experimento. Nesse órgão, as caspases 3 e 8 mostraram um comportamento molecular diferente do apresentado no baço. Ao contrário do baço, houve uma intensidade decrescente das bandas com as doses e os intervalos de tempo utilizados no presente estudo, principalmente, após 72 horas de tratamento (Fig. 4). A diminuição da expressão das caspases pode ser explicada pela grande perda celular que o timo sofreu no início do tratamento com a dexametasona. Assim, com dose e período de ação maiores, o órgão já estaria muito atrófico e não contaria mais com número tão significativo de células expressando o mRNA para as caspases 3 e 8 , isto é, as caspases 3 e 8 teriam sua expressão reduzida pela alta taxa de apoptose já ocorrida anteriormente no timo, induzida pela maior dose de dexametasona e pelo maior tempo decorrido. 


\section{Batista et al.}

\section{CONCLUSÕES}

A técnica de RT-PCR foi sensível e capaz de detectar a expressão dos mRNAs das caspases 3 e 8 , sendo uma ferramenta rápida, eficiente e segura para o estudo da expressão gênica dessas enzimas. Em ratas Wistar, as caspases 3 e 8 participam do processo de apoptose induzida por dexametasona. A apoptose induzida por dexametasona em baço e, principalmente, em timo de ratas Wistar é um modelo para o estudo da expressão das caspases 3 e 8.

\section{REFERÊNCIAS BIBLIOGRÁFICAS}

ABBAS, A.K.; LICHTMAN, A.H.; POBER, J.S. Cellular and molecular immunology. 4.ed. Philadelphia: W.B. Saunders, 2000. cap. 10: Immunology tolerance, p.208-231.

ALAM, A.; BRAUN, M.Y.; HARTGERS, F. et al. Specific activation of the cysteine protease CPP32 during the negative selection of $\mathrm{T}$ cells in the thymus. J. Exp. Med., v.186, p.1503-1572, 1997.

AMARANTE-MENDES，G.P.; GREEN，D.R. The regulator apoptotic cell death. Braz. J. Med. Biol. Res., v.32, p.1053-1061, 1999.

ARENDS, M.J.; WYLLIE, A.H. Apoptosis: mechanisms and roles in pathology. Int. Rev. Exp. Pathol., v.32, p.223-254, 1991.

CARVALHO, R.; OLIVEIRA, A.M.; SOUZA, A.M. et al. Prevalence of equine herpesvirus type 1 latency detected by polymerase chain reaction. Arch. Virol., v.145, p.1773-1787, 2000b.

CARVALHO, R.; PASSOS, L.M.F; MARTINS, A.S. Development of differential multiplex PCR assay to equine herpesvirus 1 and equine herpesvirus 4 as an aim to diagnosis investigation. J. Vet. Med., v.47, p.351-359, 2000a.

CHOMCZYNSKI, P.; SACCHI, N. Single step method of RNA isolation by acid guanidinium thiocyanate-phenol-chloroform extraction. Anal. Biochem., v.162, p.156-159, 1987.

COLLINS, J.A.; SCHANDL, C.A.; YOUNG, K.K. et al. Major DNA fragmentation is a late event in apoptosis. J. Histochem. Cytochem., v.45, p.923-934, 1997.

DISTELHORST, C.W. Recent insights into the mechanism of glucocorticosteroid-induced apoptosis. Cell Death Differ, v.9, p.6-19, 2002.
FROHMAN, M.A. Race: rapid amplification of cDNA ends. In: INNIS, M.A.; GELFAND, D.H.; SNINSKY, J.J. et al. (Eds.). PCR Protocols: a guide to methods and applications. San Diego: Academic, 1990. p.2838 .

HACKER, J. The morphology of apoptosis. Cell Tissue Res., v.301, p.5-17, 2000.

HENGARTNER, M.O. The biochemistry of apoptosis. Nature, v.407, p.770-776, 2000.

JUAN, T.S.; MCNIECE, I.K.; JENKINS, N.A. et al. Molecular characterization of mouse and rat CPP32 beta gene encoding a cysteine protease resembling interleukin-1 beta converting enzyme and CED-3. Oncogene, v.13, p.749-755, 1996.

KERR, J.F.R. Shrinkage necrosis: a distinct mode of cellular death. J. Pathol., v.105, p.13-20, 1971.

KERR, J.F.R.; SEARLE, J.A. Suggested explanation for the paradoxically slow growth rate of basal cell carcinomas that contain numerous mitotic figure. $J$. Pathol., v.107, p.41-44, 1972.

KERR, J.F.R.; WYLLIE, A.H.; CURRIE, A.R. Apoptosis: A basis biological phenomenon with wideranging implications in tissue kinetics. Br. J. Canc., v.26, p.239-257, 1972.

KING, L.B.; VACCHIO, M.S.; DIXON, K. et al. A targeted glucocorticoid receptor antinsense transgene increases thymocyte developmente. Immunity, v.3, p.647, 1995.

KRAMMER, P.H. CD95's deadly mission in the immune system. Nature, v.407, p.789-795, 2000.

KUIDA, K.; ZHENG, T.S; NA, S. et al. Decrease apoptosis in the brain and premature lethality in CP-32 deficient mice. Nature, v.384, p.368-372, 1996.

MILLS, J.C.; STONE, N.L.; PITTMAN, R.N. Extranuclear apoptosis: the role of the cytoplasm in the execution phase. J. Cell Biol., v.146, p.703-707, 1999.

MIYASHITA, T.; NAGAO, K.; KRAJEWSKI, S. et al. Investigation of glucocorticoid-induced apoptotic pathway: processing of caspase- 6 but not caspase-3. Cell Death Differ., v.5, p.1034-1041, 1998.

MULLIS, K.B.; FALOONA, F.A. Specific synthesis of DNA in vitro via a polymerase-catalyzed chain reaction. In: WU, R. (Ed.). Methods in enzymology. San Diego: Academic, 1987. v.155. p.335-350.

WYLLIE, A.H.; KERR, A.H.; CURRIE, A.R. Cell death: the significance of apoptosis. Int. Rev. Cytol., v.68, p.251-306, 1980. 